\title{
Arabic Mass Media and Women Gender Stereotype: Stability versus Change "The Dream of Women Empowerment"
}

\section{Ashraf Abdelmogeth and Heba Mossad}

Department of Mass communication, University of Bahrain, Manama, Bahrain

\section{Abstract}

Mass media play a significant role in broadcasting information that can manipulate people's attitude and opinions. Media continue on presenting men as hard, tough, independent, sexually aggressive, unafraid, violent, totally in control of all emotions, thus creating a muscular world. So, although equality between male and female is an issue lots of people have tried to achieve, yet media reflect cultural stereotypes

Corresponding Author: Ashraf Abdelmogeth

Received: 18 September 2018 Accepted: 10 October 2018 Published: 15 October 2018

Publishing services provided by Knowledge E

(c) Ashraf Abdelmogeth and Heba Mossad. This article is distributed under the terms of the Creative Commons

Attribution License, which permits unrestricted use and redistribution provided that the original author and source are credited.

Selection and Peer-review under the responsibility of the Sustainability and Resilience Conference Committee.

\section{G OPEN ACCESS} that depart markedly from reality. Hence, the purpose of this study is to explore the role of morning daily programs on woman empowerment that are broadcasted by satellite national television services in the Arabic world (Algeria and Tunisia representing West region, Egypt and Lebanon representing Middle region and Saudi Arabia and Bahrain representing Gulf region). Based on liberation theory and elimination of gender oppression, a quantitative and qualitative content analysis study was conducted to examine whether (1) media system make reality (reflects male and female balanced reality) or mirror reality (reflects male high satiates reality)? (2) socio-cultural factors that affect the role of media system in empowering women such as historical context (Past Colonial intellectual dominance-women movement). The findings showed that media system mirror reality more than make reality as males are represented in the media almost double the number as females (65\% vs. 35\%), and that still some fields are restricted to men, especially political fields (male $11 \%$ vs. $2 \%$ for female, sports $5 \%$ for male vs. $2 \%$ for female) and vice versa for educational fields ( $23 \%$ female vs. $14 \%$ for male). It seemed through the study that historical context had a great effect on women empowerment, as the highest representation of men in media was seen in the countries that were previously controlled by Britain (e.g., Egypt, Saudi Arabia and Bahrain), whereas the highest representation of women in media were of the countries that were previously controlled by France (e.g., Lebanon, Algeria and Tunisia). Also, land size seemed to affect this empowerment as the most percent of presentation of male was proved to be in the big countries compared to the smallest countries ( $74 \%$ vs. 54\%), where female were most presented in small countries compared to big ones ( $45 \%$ vs. $26 \%$ ). 


\section{Introduction}

For many centuries women was consider as the weakest part suffering from marginalization in all areas, however, there are little number of women whom took upon themselves the task of proving that trustworthy woman, if we go through history only 12 woman had been a queen in Egyptian starting from "Merneith" 2970 BC. [1] till " Shagrat al-Durr" 1250 AC. In Chinese history, "Wu Zetian" was the only woman in the history of China to assume the title of Huangdi (665-690) [2].

By the breakdown of World War II, United Nations had been established at 1945since that no female has been general secretary. Security Council the most important body of UN and its permanent members never had female president or prime minister except "Margaret Thatcher" 1979-1990 in UK Women are better off today, but still far from being equal. Racial discrimination between female and male is still alive in the 21st century. The female are in most cases treated as an inferior race by male, only 20 countries in the world have a woman in the head its governments. Only one lady "Liliane Bettencourt" is Among the top ten richest persons in the world.

Many efforts have been done to bridge the gap between human been parties "male and female", but the gapes still strongly a chasm. The Universal Declaration of Human Rights is a milestone document in the history of human rights (Drafted by representatives with different legal and cultural backgrounds from all regions of the world, the Declaration was proclaimed by the United Nations General Assembly in Paris on 10 December 1948) mention that: "Whereas the peoples of the United Nations have in the Charter reaffirmed their faith in fundamental human rights, in the dignity and worth of the human person and in the equal rights of men and women" [3] Universal Declaration of Human Rights Usually uses "human beings" Except only twice Mention "men \& women. but equal rights for men and women in fact People around the world say they firmly support equal rights for men and women, but many still believe men should get preference when it comes to good jobs, higher education or even in some cases the simple right to work outside the home [4].

The European Union has made a great effort in gender equality, but the 2010 Euro barometer survey actually included a question tapping victim-blaming attitudes, asking whether the provocative behavior of women was a cause of domestic violence. Percentages of those respondents agreeing with this statement ranged from $33 \%$ to $86 \%$ across countries, with an EU average of $52 \%$. Percentages were particularly high in countries such as Lithuania (86\%), Estonia (84\%), Cyprus (80\%) and Latvia (79\%). However, it is also surprising that some of the highest percentages were found in 
highly developed EU countries (both in economic and in gender equality terms) such as Sweden (59\%), United Kingdom (63\%), Denmark (71\%), and Finland (74\%) [5]. To sum up "we speak a lot and do a little".

Women in the first world still suffering strongly, so we expect more and more suffering in the Third World and Arab region. Organizational reality in Arab countries is that women struggle with patriarch call, male-dominated hierarchies that have a conservative orientation towards women. Moreover, in Arab countries, women have only recently began to join the rank of managers and are grossly under-represented at the lower, middle and senior levels women constitute $32.3 \%$ of the total workforce in Lebanon compared to $15 \%$ in Saudi Arabia Kuwait has seen women's participation increase by $3 \%$ between 2000 and 2005 while Saudi Arabia has witnessed a decrease from $7 \%$ in 1990 to $4 \%$ in 2003 In Bahrain, women make up $36 \%$ of all the employees in the public sector, yet their participation in the workforce increased only by $2 \%$ between 1990 and 2004 [6]. Women make up one half of society. we should Empower women in our society to participate fully in economic life across all sectors is essential to build stronger economies Our society will remain backward and in chains unless its women are liberated, enlightened and liberated, enlightened and educated [7].

Current national human resource development (NHRD) literature has not examined gender issues nor considered the governance regimes that shape national HRD systems. The Gulf States are all Islamic states. This means that governance arrangements are organized in accordance to Islamic Shari'a. There are varieties in the nature of governance regimes, but state and religious authorities are entwined. For a detailed discussion on Islamic states see The importance of limited gender studies in Arab States generally dates back to 1995 [8].

Traditional gender roles and stereotypes continue to have a strong influence on the division of roles between women and men in the home, in the workplace and in society at large, with women depicted as running the house and caring for children while men are depicted as wage-earners and protectors [9]. Gender Role Congruity Theory predicts that women would be more attracted to masculine-stereotyped occupations and men would be more attracted to feminine-stereotyped occupations if the occupations were perceived as affording goals that aligned with their gender roles [10].

Difficulties in differentiating gender roles in the modern societies can be a perfect example of the negative social effects of using stereotypes. A division of gender roles is deeply rooted in the social archetypes. In the past, the patriarchy was a dominant family model [11]. 
The international human rights law framework is concerned with gender stereotypes which is defined as overgeneralization of characteristics, differences and attributes of a certain group based on their gender. Gender stereotypes are our social and legal status as girls and boys, women and men which create a widely accepted judgment or bias about certain characteristics or traits that apply to each gender. with gender stereotypes and biases, children regularly learn to adopt gender roles which are not always fair to both sexes. If a man or a woman act differently from how their gender is assumed to behave [12].

Mass media play a significant role in a modern world, by broadcasting information in fast pace and giving entertainment to vast audiences. They consist of press, television, radio, books and the Internet. The latter is now the most developing medium, however, TV also has a wide field of influence. By creating a certain type of message, media can manipulate people's attitude and opinions [13].

In general, media continue to present both women and men in stereotyped ways that limit our perceptions of human possibilities Media, then reinforce long-standing cultural ideals of masculinity:' Men are presented as hard, tough, independent, sexually aggressive, unafraid, violent, totally in control of all emotions, and-above all-in no way feminine Media's images of women also reflect cultural stereotypes that depart markedly from reality As we have already seen, girls and women are dramatically underrepresented [14].

\section{Review of Literature}

Inequality perceived in most of the past researches made some to study this result in the media that target mainly females versus the ones that target males. Daalmans and others (2017), conducted a quantitative content analysis to examines the differences between how men and women are presented in two Dutch channels that target women versus other two that target men as well as the nature of this presentation in terms of respect. A comparison was made and the results showed as expected that men's channels presented women in a traditional unequal image compared to what women's channels did. Differently, women's channels appeared to present an equal image for both genders. As well, men's channels showed women more than men to be working on household and caregiving tasks while women's channel showed an equal image for both genders. In general, women were underrepresented, no matter the origin of production of the program analyzed on either channels [15]. 
The story begins with Taylor, Laramie (2015) when he examined the impact of media gender ratios on male audience members. One hundred thirty young adult men read a series of media narratives featuring either multiple men and a single woman or multiple women and a single man as well as a measure of endorsement of traditional masculinity and measures of romantic and sexual selectivity and confidence. Men who read the abundant partners narratives exhibited greater selectivity for marriage partners relative to control participants. Partner availability or scarcity in media narratives also influenced romantic confidence, although this was moderated by endorsement of traditional masculine ideology [16].

Even as many doubt Gustafsson, Mariev; Sikström, Sverker \& Lindholm, Torun (2015) try to test gender and media effect by examining how the pronouns She and He are used in a news media context. More specifically, the study tests whether He occurs more often and in more positive semantic contexts than She, as well as whether She is associated with more stereotypically and essential labels than He is. Study showed that He pronouns were about 9 times more frequent than She pronouns. In addition, the semantic contexts of He were more positive than the contexts of She. Moreover, words associated with She-contexts included more words denoting gender, and were more homogeneous than the words associated with He-contexts. Altogether, these results indicate that men are represented as the norm in these media [17].

Although Gutiérrez San Miguel \& other (2014) aims to identify the gender roles represented in the Spanish television programmers produced during the 1960s, 1980 s and 2000 s in order to detect the social changes that have occurred throughout these periods. The study is based on a mixed method: a survey questionnaire administered to students and professors from different postgraduate degree programmers to detect the social paradigms represented on television during the aforementioned periods, as well as the values and stereotypes that underpin them. The study results were a part of a wider innovation project funded by the University of Salamanca, the results indicated to a shift in paradigms which representation of gender roles in Spain, but this evolution has been uneven. The mistreatment of women is represented in the audiovisual texts and these representations seem to be based on the loss of the traditional identity [18]

At the level gender political communication Bystrom, Dianne and Dimitrova, Daniela (2014) study shows that women running for vice president or president of the United States as major political party candidates often are covered differently than their male opponents by the media. This study examines Republican presidential candidate Michele Bachmann's television news coverage compared to her male opponents in the months leading up to the primary stage of the 2012 campaign. The analysis shows 
that Bachmann received less coverage, which was more often written in the game than issue frame. She was more likely to be associated with masculine than feminine issues. However, Bachmann received less image and negative coverage than her male opponents [19].

As social factors and media can affect the treatment of the media, so Romero, Elaine \& other (2014) analyzed the viewpoint of gender as a relational category, the treatment of the media to athletes in major sporting events. Method: The corpus of analysis comprised 36 photos published in the Sports Section of the newspaper "0 Globo" during the year 2010 related to the impact of major sporting events. the news coverage although has given visibility to women it still put in evidence her physical attributes at the expense of her athletic performance, being this a characteristics for male athletes, making us conclude that the sports media continues to treat gender inequalities [20].

Regarding to how drama affects one's perceptions, Kharroub and Weaver (2014) conducted a content analysis study on 15 Arabic and 3 Turkish drama serials on transnational Arab television to examine how female and male characters are portrayed in these drama. The results showed that male characters were presented more than female ones and only few of the female characters (26\%) compared to male characters $(49 \%)$ were shown to have recognizable jobs. As well, almost half $(43 \%)$ of the female were shown to work in stereotypical jobs e.g. Nurses, secretaries or teachers, where only $(3 \%)$ of thee male characters occupied same jobs. On the contrary, (39\%) of male characters occupied recognized jobs e.g. Doctors, engineers. Compared to $(7 \%)$ of female characters. Marital status affected how married female characters to be presented as not to be working outside home and only to be doing housekeeping work inside home. Meanwhile when a female producer/writer is involved in producing the drama, women are presented in a more respectful and recognized context. In general female characters in programs from conservative Arab countries were shown with less recognition and respect than characters from more liberal Arab countries [21].

Stereotyping of gender went even to the point of connecting personal characteristics to ability to do business, which made Gupta and others (2009) to do a study to examine the most important relationship between the widely shared beliefs about femininity/masculinity and entrepreneurial intentions of men and women. Data was collected through a survey on young adults in the United States, India, and Turkey. The results showed that entrepreneurship was associated more to male rather than female. As well any success for women in upper level jobs was because of how these 
women see in themselves having masculine characteristics more than having feminine ones [22].

These result were even confirmed in a study conducted by Duehr and Bono (2006) to examine the relation between gender and management stereotypes or in other terms to examine if the perception to women as leaders has changed than the past 30 years or not. A sample of female/Male managers together with male/female students participated in a leadership development survey. The results showed that men are less likely to view women as having successful managerial characteristics. Though middleaged male managers perceived stereotypes about women being a leader has changed to the sake of women, male students didn't feel the same. As age is always related to the experience one acquire through life, male managers especially who had a direct experience with female managers viewed women 's stereotypes to be changing and women were viewed to be active and not passive as before. Meanwhile, in general men tend to view women as having few managerial characteristics to achieve success [23].

To understand the effect of gender stereotyping on our perception and behavior, Taylor (2003) conducted a content analysis study on the most popular books for children to examine the gender stereotypes presented in them and if they have a traditional gender role stereotypes that affects the perception of children in viewing reality around them. A sample of students were made to analyze the text, symbols, characters, use of colors and major themes in such books. The results showed that these books were presenting children with racist stereotypes about women and men (male \& female). Males were shown to always do important things playing an important role in social life, while female are in a secondary place. As well, intelligence, authority and important decisions were related to men while women are shown to be followers and their social role is cooking and cleaning [24].

Thus we can say that literature in gender stereotype proved a racist reality in favor of male and against female. This stereotype showed to be deeply rooted in the society that even most popular books for children feed them with this concept. Accordingly, an under represent of women in the media was evidenced not just on how frequent "she" is mentioned in the media compared to the pronoun "He", but even on the negative context she is related to. Women were shown to be tied to a traditional stereotype of being a follower, dependent on men and doing home tasks and parental care jobs in home. Any success a woman achieves on the social level (e.g. an athlete) or on the economic level (e.g. Entrepreneur/manager) or on the political level (e.g. as a political candidate) was interpreted that she has more muscular characteristics than feminine 
ones. In general, it seemed that all the efforts done to address gender equality resulted in women view of themselves not in men's view to women; men seemed not to be convinced of women's capability of more than being a sexual object or a worker inside her home, unless they have a direct experience with her success.

\section{Theoretical Background}

Feminist research has expanded beyond its origins in Women's Studies to influence the more traditionally bounded academic disciplines, feminism can be used to describe a political, cultural or economic movement aimed at establishing equal rights and legal protection for women [25]. Incorporating feminist and empowerment approaches in practice will provide social workers with the knowledge, values and skills most likely to promote human rights and social justice. feminism can be divided into four waves [26].

The first feminist wave was in the nineteenth and early twentieth centuries, the goal of this wave was to open up opportunities for women, with a focus on suffrage [27]. The earliest signs of feminism in the west came in the 14th century when women lead the Peasants' Revolt against British Serfdom [28]. Notably was Johanna Ferrour who ordered the violent beheading of Lord Chancellor and Archbishop of Canterbury Simon of Sudbury. The first wave of feminist movement in America is often referred to as the Suffrage Movement and early feminist activists as suffragettes, because much of their activism focused on gaining the right to vote Some claimed that women were morally superior to men, and so their presence in the civic sphere would improve public behavior and the political process. However, some feminists criticize the wave metaphor because it leaves out the ongoing activism of women throughout history, including women's efforts to challenge the institutions and practices of patriarchy in the many centuries preceding the 1800 [ [29].

The second was in the 1960s and 1970s, The feminist movement of the 1960 s and '70s originally focused on dismantling workplace inequality, such as denial of acing 1970s, feminist activists began to witness the fruits of their labors in earnest. In 1972, Wasess to better jobs and salary inequity, via anti-discrimination laws. hington, D.C., established the first rape crisis hotline, and the Supreme Court legalized abortion via Roe v. Wade in 1973 [30]. This wave unfolded in the context of the anti-war and civil rights movements and the growing self-consciousness of a variety of minority groups around the world. The New Left was on the rise, and the voice of the second wave was increasingly radical [31]. In large part, the success of the feminist movement was driven 
by a favorable confluence of economic and societal changes [32]. At the same time, the movement used class action lawsuits, formal complaints, protests, and hearings to create legal change. The second wave was increasingly theoretical, based on a fusion of neo-Marxism and psycho-analytical theory, and began to associate the subjugation of women with broader critiques of patriarchy, capitalism, normative heterosexuality, and the woman's role as wife and mother [33].

The third wave is described as focusing little on any type of political agenda, but putting effort toward breaking the boundaries and conceptions of gender and also being heavily inclusive of men Third wave feminism differentiates itself from second wave feminism with the approach it offers to overcoming some of the impasses which developed in feminist theory in the 1980s. This wave of feminism is strongly characterized by the use of communication especially social media to raise awareness on women issues. Sex and gender were differentiated-the former being biological [34], and the later a social construct that varies culture-to-culture and over time. Third wave feminism was built around being more inclusive for people of color and being who do not adhere to the gender binary, yet White Feminism and Trans Exclusionary Radical Feminism are still issues under the feminist umbrella, and the third extends from the 1990 s to the present. Feminist theory emerged from these feminist movements. In this phase many constructs were destabilized, including the notions of "universal womanhood," body, gender, sexuality and heteronormativity [35]. It is manifest in a variety of disciplines such as feminist geography, feminist history and feminist literary criticism. Feminist identification served as a mediator between gender socialization (encouragement of education for marriage and family and discouragement of othergender characteristics) and daughter present and future selves [36].

We have been in a fourth wave since 2008 - that in the environment of online social media has flourished geometrically and is poised to be the most swiftly moving wave of feminism yet - we are focused on global social justice, intersectionally representing women of all ages, races, sexual orientations, and classes, of a spirituality that includes a reflection of the feminine and a psychology that centers on self-actualization through pleasure. The fourth wave of feminism is still a captivating silhouette [37]. The existence of a feminist 'fourth wave' has been challenged by those who maintain that increased usage of the internet is not enough to delineate a new era. The feminist consciousness of the fourth wave has also been forged through the years of the financial crash and the coalition government, and many activists have been politicized and influenced by other movements, particularly the student campaign against fees, but also the wider campaign against cuts and the Occupy movement. Online Feminism, 
a report recently published by Columbia University's Barnard Center for Research on Women, females aged between 18 and 29 are the 'power users of social networking'. According to this research, the number of women using digital spaces is increasing [38].

\section{Study Purpose}

In the midst of ongoing fourth wave of feminism discussions, about media and woman empowerment, this study aims to explore role of morning daily programs woman empowerment, that are broadcasted by satellite national television services in the Arabic world (West region, Middle region and Gulf region), Through quantitative and qualitative content analysis study.

\section{Study Questions}

This study seeks to answer a two main questions:

1. Does media system make reality (reflects male and female balanced reality) or mirror reality (reflects male high satiates reality)?

2. What are the factors which affect the role of media system in empowering women?

- Natural factors (e.g. population - Land)

- Or socio-political factors

(e.g., Past Colonial intellectual dominance- women movement).

\section{Research Methods}

Quantitative research focuses on gathering numerical data and generalizing it across groups of people or to explain a particular phenomenon. Quantitative research aims to is to provide a complete, detailed description of the research topic. It is usually more exploratory in nature and focuses more in counting and classifying features and constructing statistical models and figures to explain what is observed [39]. 


\section{Content Analyses}

This study was carried out through Content analysis and discourse analysis to describe the tasks which are described below

1. Social gender

- Male

- Female

2. Type of personality

- Realistic

- Cartoons

- Artistic

3. Photoaged Location

- work place

- Social place

- Other

4. Type of the job

- Traditional functions

- Contemporary Jobs

5. Active force

- actor

- Supporter

- Marginal actor

6. Issues

- Social issues

- Religious issues

- Political issues

- Sports issues

- Other 


\section{Sample}

The sample consists of 7 mooring program series (weekdays), total of 56 series, form six Arab countries, Algeria and Tunisia \& Egypt and Lebanon \&, Saudi Arabia and the Bahrain Kingdom (the largest and smallest country In population and land, from West region - Middle region - East region).

\subsection{Reliability and validity}

The validity Content analyses tool was tested through judgment process (3 professors), and reliability was carry out through, "test and retest" Technique on two level first level was over time and second level through the researchers. (And the correlation coefficient across the second level) [40].

\subsection{Data collection}

Structured content analyses tool and definition operation manual was prepared, after pre-test and reliability and validity procedures took place, data gathering process started from 1 October 2017 to 31 December 2017.

\section{Results}

\subsection{General results}

1. Does media system make reality (reflects male and female balanced reality)or mirror reality (reflects male high satiates reality)?

The results showed that media system mirror reality (reflects male high satiates reality) rather than making reality (reflects male and female balanced reality) Gender Presentation in the media (Table 1)

TABLE 1

\begin{tabular}{|l|c|c|}
\hline & Frequency & Percent \\
\hline Male & 441 & 65.2 \\
\hline Female & 235 & 34.8 \\
\hline Total & 676 & 100.0 \\
\hline
\end{tabular}

As male characters from over all the sample were presented doubled the female ones (65.2\% versus 34.8\%).,(Table 1 ). 
TABLE 2: Gender * country Cross tabulation.

\begin{tabular}{|c|c|c|c|c|c|c|c|c|c|}
\hline & & & \multicolumn{6}{|c|}{ country } & \multirow[t]{2}{*}{ Total } \\
\hline & & & Algeria & Tunisia & Egypt & Lebanon & $\begin{array}{l}\text { Saudi } \\
\text { Arabia }\end{array}$ & Bahrain & \\
\hline \multirow[t]{4}{*}{ gender } & \multirow[t]{2}{*}{ male } & Count & 74 & 73 & 108 & 35 & 90 & 61 & 441 \\
\hline & & $\begin{array}{l}\text { \% within } \\
\text { country }\end{array}$ & $51.7 \%$ & $57.5 \%$ & $85.7 \%$ & $46.7 \%$ & $75.0 \%$ & $71.8 \%$ & $65.2 \%$ \\
\hline & \multirow[t]{2}{*}{ female } & Count & 69 & 54 & 18 & 40 & 30 & 24 & 235 \\
\hline & & $\begin{array}{l}\text { \% within } \\
\text { country }\end{array}$ & $48.3 \%$ & $42.5 \%$ & $14.3 \%$ & $53.3 \%$ & $25.0 \%$ & $28.2 \%$ & $34.8 \%$ \\
\hline \multirow[t]{2}{*}{ Total } & & Count & 143 & 127 & 126 & 75 & 120 & 85 & 676 \\
\hline & & $\begin{array}{l}\text { \% within } \\
\text { country }\end{array}$ & $100.0 \%$ & $100.0 \%$ & $100.0 \%$ & $100.0 \%$ & $100.0 \%$ & $100.0 \%$ & $100.0 \%$ \\
\hline
\end{tabular}

Egypt was the most country where male were over presented (85.7\%) followed by Saudi Arabia (75\%), Bahrain (71.8\%), Tunisia (57.5\%), Algeria (51.7\%), then the least percentage in Lebanon (46.7\%)

In which a significant presentation was proved over the six countries that were included in the study where $\mathrm{X} 2(5, \mathrm{~N}=676)=56.185, \mathrm{p}>.000$ (table 5$)$ showing that women were differently presented by the difference of country.

TABLE 3: Types of jobs * gender Cross tabulation.
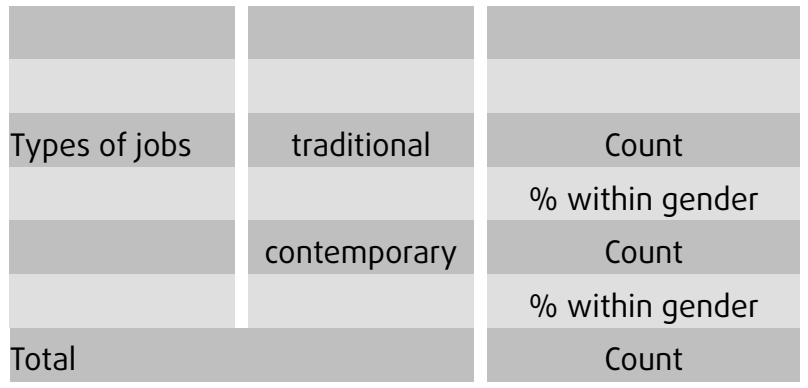

\begin{tabular}{|c|c|c|}
\hline \multicolumn{2}{|c|}{ gender } & Total \\
\hline female & male & \\
\hline 179 & 66 & 245 \\
\hline $40.6 \%$ & $28.1 \%$ & $36.2 \%$ \\
\hline 262 & 169 & 431 \\
\hline $59.4 \%$ & $71.9 \%$ & $63.8 \%$ \\
\hline 441 & 235 & 676 \\
\hline
\end{tabular}

The results showed that female were more tied to traditional roles (40.6\%) compared to male (28.1\%) and vice versa for contemporary roles as male were double presented in the media coverage $(71.9 \%)$ compared to only $(59.4 \%)$ for female (Table 3).

Thus the relation between type of job and gender examined in the media coverage in the present study was significantly proved where $x_{2}(1, N=676)=$ 10.374, p>.001 (table 3) showing that women when presented has to be under the patronage of the government but men were brave enough to undergo and achieve contemporary jobs.

Gender presentation through the present study showed no difference on the basis of being an actor or supporter or even reflecting a marginal role. That is 
TABle 4: Active Force * gender Cross tabulation.

\begin{tabular}{|c|c|c|c|c|c|}
\hline & & & \multicolumn{2}{|c|}{ gender } & Total \\
\hline & & & male & female & \\
\hline \multirow[t]{6}{*}{ Active Force } & actor & Count & 152 & 87 & 239 \\
\hline & & $\%$ within gender & $34.5 \%$ & $37.0 \%$ & $35.4 \%$ \\
\hline & supporter & Count & 236 & 119 & 355 \\
\hline & & $\%$ within gender & $53.5 \%$ & $50.6 \%$ & $52.5 \%$ \\
\hline & marginal & Count & 53 & 29 & 82 \\
\hline & & $\%$ within gender & $12.0 \%$ & $12.3 \%$ & $12.1 \%$ \\
\hline \multirow[t]{2}{*}{ Total } & & Count & 441 & 235 & 676 \\
\hline & & $\%$ within gender & $100.0 \%$ & $100.0 \%$ & $100.0 \%$ \\
\hline
\end{tabular}

when male were presented as an actor force (34.5\%), female were presented with a slightly different percentage $(37 \%)$. As well when male were presented as doing a marginal role (12\%), female were presented in about the same percentage $(12.3 \%)$ (Table 4$)$.

\begin{tabular}{|c|c|c|c|}
\hline & Value & df & $\begin{array}{c}\text { Asymp. Sig. } \\
\text { (2-sided) }\end{array}$ \\
\hline Pearson Chi-Square & $.538 a$ & 2 & .764 \\
\hline
\end{tabular}

Reflecting the above results, active Force and gender didn't prove to be significantly, as $X_{2}(2, N=676)=.538, p>.764$

This media presentation even assured the traditional view of the role of women to be tied in teaching (22.6 \% female/14.1 \% male) and art craft ( $18.3 \%$ female/8.8 $\%$ male), while male to be in more serious rational and powerful fields like politics (10.7 \% male/1.7 \% female), religion ( $4.1 \%$ male/o \% female) and sports ( $5.4 \%$ male/1.7 \% female) (table 5).

This even was significantly clear, where $x^{2}(6, N=676)=52.66, p>.000$ indicating that there is still some jobs restricted to a specific gender.

2. What are the factors, which affect the role of media system in empowering women?

It is clear from the results that socio political factors play an important role in women empowerment in the society.

It is clear from the results that socio political factors play an important role in women empowerment in the society as past colonial intellectual dominance showed to play a significant role in this relation (table 4$)$, where $X_{2}(1, N=676)=48.4, p>.000$ showing that women in the countries (Tunisia, Lebanon \& Algeria) that were previously 
TABle 5: Issue * gender Cross tabulation.

\begin{tabular}{l|l} 
& \\
issue & social \\
& religion \\
& political \\
& sport \\
& educational \\
\hline cultural/development \\
\hline Total & \\
\hline & \\
\hline & \\
\hline & \\
\hline & \\
\hline & \\
\hline
\end{tabular}



Pearson Chi-Square

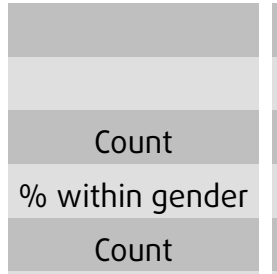

$\%$ within gender

Count

$\%$ within gender

Count

$\%$ within gender

Count

$\%$ within gender

Count

$\%$ within gender

Count

$\%$ within gender

Count

$\%$ within gender

Value

$\mathrm{df}$

$52.668 a$

\begin{tabular}{|c|c|c|}
\hline \multicolumn{2}{|c|}{ gender } & Total \\
\hline male & female & \\
\hline 243 & 121 & 364 \\
\hline $55.1 \%$ & $51.5 \%$ & $53.8 \%$ \\
\hline 18 & 0 & 18 \\
\hline $4.1 \%$ & $.0 \%$ & $2.7 \%$ \\
\hline 47 & 4 & 51 \\
\hline $10.7 \%$ & $1.7 \%$ & $7.5 \%$ \\
\hline 24 & 4 & 28 \\
\hline $5.4 \%$ & $1.7 \%$ & $4.1 \%$ \\
\hline 62 & 53 & 115 \\
\hline $14.1 \%$ & $22.6 \%$ & $17.0 \%$ \\
\hline 8 & 10 & 18 \\
\hline $1.8 \%$ & $4.3 \%$ & $2.7 \%$ \\
\hline 39 & 43 & 82 \\
\hline $8.8 \%$ & $18.3 \%$ & $12.1 \%$ \\
\hline 441 & 235 & 676 \\
\hline $100.0 \%$ & $100.0 \%$ & $100.0 \%$ \\
\hline & & \\
\hline
\end{tabular}

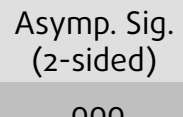

TABLE 6: Chi Square Tests between Past Colonial intellectual dominance * Gender.

\begin{tabular}{|l|c|c|c|}
\hline & Britain & France & Total \% \\
\hline Male $\%$ & 78.2 & 52.8 & 65.2 \\
\hline Female $\%$ & 21.8 & 47.2 & 34.8 \\
\hline
\end{tabular}

empowered by France were more presented in the media $47.2 \%$ compared to those countries (Egypt, Saudi Arabia \& Bahrain) that were previously empowered by Britain $21.8 \%$ (Table 6).

TABLE 7: Chi Square Tests between Region* Gender.

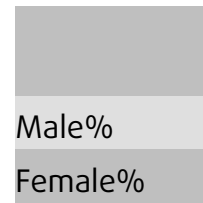

West Region
$\begin{gathered}54.4 \\ 45.6\end{gathered}$

Middle
Region
71.1
28.9

Gulf Region
$\begin{gathered}73.7 \\ 26.3\end{gathered}$

Total \%
65.2
34.8

Gender was proved through the present study to be differently presented in the media by the difference of the region, where male were most presented in Gulf region 
(Saudi Arabia-the Bahrain Kingdom 73.7\%), followed by the middle region (EgyptLebanon 71.1\%) followed by the west region (Algeria - Tunisia 54.4\%). On the contrary, female were most presented in west region (45.6\%) followed by middle region $(28.9 \%)$, then the least in Gulf region (26.3\%) (Table 7). In which this indicated that women were most empowered in the west region, where least empowered in Gulf region.

Thus Gender and region were proved by the results to have a significant effect where $X_{2}(2, N=676)=23.3, p>.000$ (table 7) showing that women were more presented in the west region $45.6 \%$, compared to $28.9 \%$ in the middle region and $26.3 \%$ in the gulf region

TABLE 8: Chi Square Tests between Population/Land * Gender.

\begin{tabular}{|l|c|c|c|}
\hline & Big & Small & Total $\%$ \\
\hline Male\% & 69.9 & 58.9 & 65.2 \\
\hline Female\% & 30.1 & 41.1 & 34.8 \\
\hline
\end{tabular}

Difference in size of the country reflected difference in how gender is presented in the media where male where more presented in big countries (69.9\%) versus (58.9\%) for small countries. Meanwhile female were more presented in small countries $(41.1 \%)$ versus $(30.1 \%)$ in big countries (Table 8 ).

Land/population was significantly proved to affect how gender is presented in the media (Table 8) as X2 $(1, N=676) 8.872=, p>.003$, in which countries that are classified as big (Egypt-Saudi Arabia-Algeria) men were more presented 69\% compared to only half of this percent $30.1 \%$ of women, but this difference was less in small countries (Tunisia-Lebanon-Bahrain) where men were presented $58.9 \%$ compared to $41.1 \%$ of women.

\section{Conclusion}

This study examined if the presence of women in Arab media is reflecting the voices that are calling for gender equality in Arab countries or reflecting an in equal gender situation. Six countries were taken as a sample representing different region with different historical background. The results were consistent with what previous researches found regarding the outnumber presentation of male characters than female characters in the media [41]. As well female being tied to the field of teaching and art craft while male to be related to politics, sport and religion went along with what other researches described for specific jobs to be restricted to female like art and language, 
while science, math [42]; same like what others proved that upper level jobs were related to male while secondary level jobs to female [43] especially if contributing this result to how male were presented in contemporary jobs compared to female who were shown to be tied to the traditional jobs. In other means proving what other studies went to prove that success and superiority is still tied to male gender [44]. As past colonial intellectual dominance showed to play a significant role in gender equality in our study where gender equality is less in the countries that were past empowered by Britain compared to the countries that were past empowered by France, it could be explained in terms of the statistics that showed that UK ranks as one of the worst countries in Europe for gender equality at work [45] recording it as the 11th out of 18 countries behind the US, France, Spain and Sweden. Size of land/population proving to have a relation with how gender equality is practiced in Arab Media where gender inequality was clear in big countries compared to those of small sized ones, could be explained in terms that the more the country big in land and population, the more complicated the matter and vice versa when the country is small in land/population where the gap in how male and female are presented in the media is less. Results showing that gender inequality varied across countries, is consistent with what other researchers found regarding how liberal/conservative the country is in relation to gender equality practiced in such country (jobemprint); as Female characters in Saudi (50.0\%) were more likely to be shown as homemakers, compared to (25.0\%) as being the least percentage found in Lebanon. The overall results of the study reveals an inconsistency of what voices call for women empowerment in Arab societies and the actual situation, where the issue of gender inequality seems to be theoretically adopted more than virtually practiced.

\section{References}

[1] http://www.angelfire.com/la/egyptology/queens.html

[2] Buenaobra, John Ray (2016) Chinese History, 173 http://www.academia.edu/ 11090060/Chinese_History

[3] United Nations (2016) Universal Declaration of Human Rights, http://www.un.org/ en/universal-declaration-human-rights/

[4] Ojalvo, Holly Epstein (2010) Do You Believe in Equal Rights for Women and Men? The learning network with NEW WORK TIMES July 2, 2010 5:17 am http://learning.blogs.nytimes.com/2010/07/02/do-you-believe-in-equal-rightsfor-women-and-men/?_r=o 
[5] Gracia,Enrique\& Lila Marisol (2015) Attitudes Towards Violence Against Women in The Eu Luxembourg, Publication Office of The European Union, 76 ISBN 978-92-7953404-1

[6] Kauser, Saleema \& Tlaiss, Hayfaa (2011) The Arab Women Manager: Participation, Barriers, and Future Prospects,Journal Of International Business And Economy,12,(1) 35-56

[7] Nadje Sadig Al-Ali,(2007)Iraqi Women: Untold Stories from 1948 to The Present, London, ZED book, pP 131-132 https://books.google.com.bh/books?isbn= 1842777459

[8] Metcalf, Beverly Dawn,(2011) Women, Empowerment And Development in Arab Gulf States: a Critical Appraisal of Governance, Culture and National Human Resource Development (HRD) Frameworks, Human Resource Development International, 14, (2), 131-148

[9] European Parliament (2012) Plenary Sitting. on Eliminating Gender Stereotypes in The Eu (2012/2116(Ini)) $\mathrm{Pe}<\mathrm{NoPE}>491.091</$ NoPE $><$ Version $>$ v02-00 Rr\921620en.Doc http://www.Europarl.Europa.Eu/Sides/Getdoc.Do?Pubref= -//Ep//Text+Report+A7-2012-0401+o+Doc+Xml+Vo//En

[10] Barth, Joan et al. (2015) Untangling Life Goals and Occupational Stereotypes in Men's and Women's Career Interest, Sex Roles., 73 (11-12), 502-518.

[11] Wolska, Malgorzata (2011), Gender Stereotypes In Mass Media. Case Study: Analysis of The Gender Stereotyping Phenomenon in TV Commercials, http://krytyka.org/gender-stereotypes-in-mass-media-case-study-analysisof-the-gender-stereotyping-phenomenon-in-tv-commercials/

[12] The Movement Against Bullying (2015) Teens Bullied Teen The Teen Bully The Bystander Internet Safety for Teens School Life Parents Parents' Coaching Parenting Help Parents' Tips Understand Bullying Teachers Bullying in Schools Teachers' Advice Teachers' Resources Types of Bullying Cyber Bullying Abuse Anti Bullying Help Bullying Tips Bullying Laws Health \& Wellbeing Phobias \& Fears Relationships Syndromes \& Disorders Wellbeing Learning Disabilities Depression Suicide Bullying Help Health Professionals Bullying Experts About Us About Us Sponsor US Blog Contact Us Gender Stereotypes: Definition, Examples and Analysis Published: March 09,2015 Http://Nobullying.Com/Gender-Stereotypes/

[13] Wolska, Malgorzata (2011), Gender Stereotypes in Mass Media. Case Study: Analysis of The Gender Stereotyping Phenomenon in TV Commercials, http://krytyka.org/gender-stereotypes-in-mass-media-case-study-analysisof-the-gender-stereotyping-phenomenon-in-tv-commercials/ 
[14] Wood, Julia T. (nd) Gendered Media: The Influence of Media on Views of Gender http://www.udel.edu/comm245/readings/GenderedMedia.pdf From Julie T. Wood(1994) Gendered Lives: Communication, Gender, and Culture, Chapter 9, pp. 231-244. Reprinted with permission of Wadsworth Publishing, a division of Thomson Learning

[15] Daalmans1,Serena \& Kleemans,Mariska \& Sadza1, Anne, (2017): Gender Representation on Gender-Targeted Television Channels a Comparison of Female- and Male-Targeted TV Channels in the Netherlands, Published online: 5 January,\# The Author(s) 2017. This article is published with open access at Springerlink.com

[16] Taylor, Laramie (2015) Men's Sexual Selectivity, Romantic Confidence, and Gender Ratios in The Media. Journal of Men's Studies, 23, (1), 107-113

[17] Gustafsson, Mariev; Sikström, Sverker \& Lindholm, Torun (2015) 'She' and 'He' in News Media Messages: Pronoun Use Reflects Gender Biases in Semantic, Sex Roles, $72,(1-2), 40-49$

[18] Miguel, Gutiérrez San; et al. (2014), Gender Roles and The Spanish Media, a ThreeDecade-Long Comparative Study, Revista Latina de Comunicación Social, 69, 213228

[19] Bystrom, Dianne \& Dimitrova, Daniela (2014) Migraines, Marriage, and Mascara: Media Coverage of Michele Bachmann in The 2012 Republican Presidential Campaign, American Behavioral Scientist, 58, (9), 1169-1182

[20] Romero, Elaine et al. (2014) Women in The Sports Press: Images and Words, Revista Salusvita., 33,(3), 285-308

[21] Kharroub,Tamara \& Weaver, Andrew (2014), Portrayals of Women in Transnational Arab Television Drama Series, Broadcast Education Association Journal of Broadcasting \& Electronic Media 58(2), 179-195

[22] Gupta, Vishal K., et. al (2009) The Role of Gender Stereotypes in Perceptions of Entrepreneurs and Intentions to Become an Entrepreneur, ENTREPRENEURSHIP THEORY and PRACTICE, Baylor University

[23] Duehr,Emily \& Bono, Joyce E. (2006) Men, Women, And Managers: Are Stereotypes Finally Changing? Personnel Psychology,(59), 815-846 University Of Minnesota, Twin Cities

[24] Taylor, Frank (2003) Content Analysis and Gender Stereotypes in Children's Books, Teaching Sociology, (31),3.300-311

[25] Casad, \& Kasabian. (2009). Feminism. in J. M. Levine, \& M. A. Hogg (Eds.), Encyclopedia of group processes and intergroup relations. Thousand Oaks, CA: Sage 
Publications. Retrieved from https://search.credoreference.com/content/entry/ sagegpir/feminism/o

[26] Mink, Gwedolyn and Smith, Barbara.(1999) "Feminisms." Mankiller, et al. The Reader's Companion to U.S. Women's History. Houghton Mifflin Harcourt. (Feb. 3, 2009) http://books.google.com/books?id=dglhBw8t410C\&printsec= frontcover\&dq=The+Reader\%27s+Companion+to+American+History\#PRA3PA192, M1

[27] Napikoski, Linda.(2009) "Goals of Feminist Movement." About. August 10, $\quad$ http://womenshistory.about.com/od/feminism/a/ feminist_movement_goals_in_the_6os_and_70s.htm

[28] Freedman, E.B. (2002) No Turning Back: The History of Feminism and The Future of Women.: Ballantine, New York; 56-58

[29] N, Musiker \& R, Musiker (2000) A Concise Historical Dictionary of Greater Johannesburg, Francolin Publishers, Cape Town. 146

[30] Amanda L. Higgins,(2013) Instruments of Righteousness: The Intersections of Black Power and Anti-Vietnam War Activism in The United States, 19641972, University of Kentucky UKnowledge, https://uknowledge.uky.edu/cgi/ viewcontent.cgi?referer= https://www.google.com.bh/\&httpsredir=1\&article= 1010\&context=history_etds

[31] Sullivan, Patricia.(2006) "Voice of Feminism's 'Second Wave.'" Washington Post. 5 Feb. 2006

[32] Schlafly, Phyllis. (2007)"'Equal Rights' for Women: Wrong Then, Wrong Now." Los Angeles Times, 8 April 2007

[33] Jones, Jacqueline.(2009) Labor of Love, Labor of Sorrow: Black Women, Work, and the Family, from Slavery to the Present. New York: Basic Books, 124

[34] Wolf, Susan M., Feminism \& Bioethics: Beyond Reproduction (1996). Susan M. Wolf, Feminism and Bioethics: Beyond Reproduction, New York: Oxford University Press, Available at SSRN: https://ssrn.com/abstract $=1735656$

[35] Kwon, I. (2013). "Gender, Feminism and Masculinity in Anti-Militarism: Focusing on the Conscientious Objection Movement in South Korea." International Feminist Journal of Politics 15 (2): 213-233

[36] Cruea, Susan (2005) Changing Ideals of Womanhood During the Nineteenth-Century Woman Movement, Changing Ideals of Womanhood During the Nineteenth-Century Woman Movement, General Studies Writing Faculty Publications, https://pdfs. semanticscholar.org/78a3/4b180d4d91559fdcb46b44275d52ca387e16.pdf

[37] Rojek, Chris (1991). PhD thesis, http://theses.gla.ac.uk/2507/1/1991rojekphd.pdf 
[38] Martin,Courtney \& Valenti, Vanessa,(2012) FemFuture: Online Revolution Published by The Barnard, Center for Research on Women, 1(34) http://bcrw.barnard.edu/ wp-content/nfs/reports/NFS8-FemFuture-Online-Revolution-Report.pdf

[39] Carrie Williams(2007) Research Methods, Journal of Business \& Economic Research - March, Volume 5, Number 3 Pp 65-72. file:///C:/Users/ashraf/Downloads/2532Article\%20Text-10126-1-10-20110207.pdf

[40] Krippendorff, K. (2004). Reliability in Content Analysis: Some Common Misconceptions and Recommendations. Human Communication Research, 30 (3), 411-433. https://doi.org/10.1111/j.1468-2958.2004.tboo738.x https://repository. upenn.edu/cgi/viewcontent.cgi?article $=1250 \&$ context=asc_papers

[41] Kharroub, Tamara \& Weaver, Andrew (2014) op.cit, 179-195

[42] Nosek,Brian \&. Banaji, Mahzarin,\& Greenwald, Anthony (2002) Math _ Male, Me _ Female, Therefore Math _ Me, Journal of Personality and Social Psychology, the American Psychological Association, Inc.(83) 1, 44-59

[43] Gupta, Vishal K., et al (2009) The Role of Gender Stereotypes in Perceptions of Entrepreneurs and Intentions to Become an Entrepreneur ENTREPRENEURSHIP THEORY and PRACTICE, Baylor University

[44] Pines, Ayala\& Lerner, Miri \& Schwartz, Dafna (2010), Gender Differences in Entrepreneurship Equality, Diversity and Inclusion in Times of Global Crisis, Equality, Diversity and Inclusion: An International Journal (29) 2,186-198

[45] UK ranks as one of the worst countries in Europe for gender equality at work, Glassdoor finds The UK ranked 11th out of 18 countries - behind the US, France, Spain and Sweden Zlata Rodionova Wednesday 18 May 2016 07:50 BS, https: //www.independent.co.uk 